\title{
Research on Impacts of Higher Education on the Employment Growth in Shandong Province
}

\author{
Fang Zhao \\ Business School, \\ University of Jinan, \\ Jinan, China \\ E-mail: se_zhaof@ujn.edu.cn
}

\author{
Yong-Jun Sun \\ Economic Development Bureau, \\ Jinan Industrial Park, \\ Jinan, China \\ E-mail: xiaobao8558@sina.com
}

\author{
Xiao-Jun Liu \\ University of Jinan, \\ Jinan, China \\ E-mail: 763682271@qq.com
}

\begin{abstract}
In the context of China's New Normal, the economy of Shandong Province is facing severe challenge, and the employment situation are also deeply affected. In this paper, we make an empirical research on the factor of higher education, which influences labor employment growth of Shandong Province. The study shows that: the growth of higher education enrollment is positively related to the number of employment. It will create $\mathbf{1 0 . 1}$ thousand job positions when higher education enrollment growth rate increases every 1 percent. Based on the above result, this paper proposes to promote the establishment of new higher education system to boost employment and entrepreneurship, and also create a large well-known vocational education group in order to advance the employment growth in Shandong Province.
\end{abstract}

Key words-higher education; employment growth; influence factors; Shandong Province

\section{INTRODUCTION}

Under the China's new normal background, Chinese economy is facing severe challenges [1]. In order to seek a new driving force for economic growth, Shandong Province must give full play to the basic role of market forces in allocating resources to ease the transfer of labor force. The impact of this process on employment in Shandong Province is inevitable. Therefore, it is of great significance for Shandong Province and even the whole country to actively deal with the relationships among structural adjustment, steady growth and employment promotion. Through the expansion of employment promote the coordinated development of economy and society.

From the perspective of labor economics, human resource is a potential power for the development of a country and a region. The factor of education has significant influence on the growth of employment in Shandong Province. This paper mainly adopts the index analysis of the growth rate of the enrollment of higher education in Shandong Province. From the perspective of labor economics, human resources development is the potential power of a country or region. The proportion of higher education determines the overall employment status within the region. The empirical analysis shows that the employment elasticity of the labors who accept higher education is normally more flexible. The employment situation of high quality talents is more dependent on the development of social economy [2]. In recent years, the colleges and universities continue to expand enrollment in Shandong Province, even in China, the number of graduates gradually increased with the growth rate of enrollment. Consequently, it arises "the hardest job season in history". A huge crowd waiting for employment has brought great impact on the labor market. The serious deviation between supply and demand leads to the change of employment structure, especially in the background of economic soft landing of China. For this reason, how to correctly understand the impact of higher education on employment in Shandong province is very necessary. The employment in Shandong is severely tested due to the sustained growth in the number of graduates and the gradual slowdown in economic growth. Therefore, this paper chooses the related data such as higher education enrollment growth rate from the year of 1990 to 2013 in Shandong Province for the sample to analyze the impact of higher education on the growth of employment and employment structure in an empirical perspective.

\section{DATA SOURCES AND DESCRIPTIVE STATISTICS}

In order to ensure the consistency and comparability of the data, all the variables of the data are from China Statistical Yearbook and Shandong Statistic Year Book [3]. The employment of Shandong Province refers to the total number of jobs in the Province's three industries. The actual GDP growth rate is based on the economic growth rate in 1990. The growth rate of higher education enrollment is the growth rate of Junior college or above enrollment over the years in Shandong. Labour stands for employment in the three industries. Llabour is on behalf of the Province's employment of logarithm value. Degrowth is the first-order differential data of the actual GDP growth rate over the years based on 1990, namely the added value of the economic growth rate. Education represents the growth rate of enrollment in higher education. The empirical analysis used in this paper all use EVIEWS8.0 to complete. Descriptive statistics of the variables are shown in Table 
TABLE I. DESCRIPTIVE STATISTICS OF VARIABLES

\begin{tabular}{l|l|l|l|l|l|l|l}
\hline Variable Name & $\begin{array}{l}\text { Observed } \\
\text { Value }\end{array}$ & $\begin{array}{l}\text { Mean } \\
\text { Value }\end{array}$ & Median & $\begin{array}{l}\text { Maximum } \\
\text { Value }\end{array}$ & $\begin{array}{l}\text { Minimum } \\
\text { Value }\end{array}$ & $\begin{array}{l}\text { Standard } \\
\text { Deviation }\end{array}$ & $\begin{array}{l}\text { Skewness } \\
\text { kurtosis }\end{array}$ \\
\hline Labour & 24 & 5491.62 & 5501.15 & 6580.40 & 4043.20 & 777.50 & -0.3915 \\
Degrowth & 23 & 0.0160 & 0.0045 & 0.0928 & -0.0007 & 0.0314 & 2.0734 \\
Education & 23 & 0.1355 & 0.0534 & 0.6408 & -0.0449 & 0.1927 \\
Llabour & 24 & 8.6008 & 8.6127 & 8.7919 & 8.3405 & 0.1480 \\
Lprimary & 24 & 6.7072 & 6.6482 & 7.2971 & 6.0528 & 0.3656 & -0.6012 \\
Lsecondary & 24 & 6.8620 & 6.8723 & 7.1068 & 6.4552 & -0.0511 \\
Lthirdary & 24 & 8.1902 & 8.1558 & 10.0528 & 6.1091 & 2.3087 & 0.1910 \\
\hline
\end{tabular}

\section{UNIT ROOT TEST}

According to the basic theory of co-integration test, there may be a long-term stable equilibrium relationship between variables, only when the selected variables are stable. So, before doing the analysis, we need to do the ADF unit root test for the original data. The basic principle of the

$\mathrm{ADF}$ unit root test is as follows:

$$
\Delta \mathrm{X}_{t}=\alpha+\beta t+\delta \mathrm{X}_{t-1}+\sum_{i=1}^{k} \theta_{i} \Delta \mathrm{X}_{t-1}+\varepsilon_{i}
$$

Among the axiom, $\alpha, \beta, \delta, \theta$, is parameters, $\mathrm{t}$ is time tendency item. The results of ADF unit root test are shown in table 2 .

TABLE II. ADF UNIT ROOT TEST RESULTS

\begin{tabular}{l|l|l|l|l|l}
\hline Variable Name & Inspection Form & ADF Statistic & $\mathbf{1 \%}$ Critical Value & $\mathbf{5 \%}$ Critical Value & 10\% Critical Value \\
\hline \multirow{3}{*}{ Labour } & $(\mathrm{C}, 0,0)$ & -1.3513 & -3.7529 & -2.9981 & -2.6388 \\
& $(\mathrm{C}, \mathrm{T}, 5)$ & $-3.9399^{* *}$ & -4.5716 & -3.6908 & -3.2869 \\
& $(0,0,0)$ & 2.9708 & -2.6694 & -1.9564 & -1.60850 \\
Degrowth & $(\mathrm{C}, 0,0)$ & $-4.8344^{* * *}$ & -3.7696 & -3.0049 & -2.6422 \\
& $(\mathrm{C}, \mathrm{T}, 0)$ & $-4.7161^{* * *}$ & -4.4407 & -3.6329 & -3.2547 \\
& $(0,0,0)$ & $-4.9480^{* * *}$ & -2.6743 & -1.9572 & -1.6082 \\
Education & $(\mathrm{C}, 0,0)$ & $-4.5181^{* * *}$ & -3.7696 & -3.0049 & -2.6422 \\
& $(\mathrm{C}, \mathrm{T}, 0)$ & $-3.2639^{*}$ & -4.4407 & -3.6329 & -3.2547 \\
& $(0,0,0)$ & $-2.3689^{* *}$ & -2.6743 & -1.9572 & -1.6082 \\
\hline
\end{tabular}

Note: Three ADF test methods (C, T, K), which, $\mathrm{C}$ said with constant unit root test, $\mathrm{T}$ said with a time trend of the unit root test, $\mathrm{K}$ for the lag term.

According to the results of the ADF unit root test of the original data, two selected variables are steady, one is the employment of Shandong Province, and another is the growth rate of higher education enrollment. So we can use the above data to carry on the regression analysis.

\section{IMPACTS OF HIGHER EDUCATION ON EMPLOYMENT GROWTH:}

Model setup:

$$
\text { Labour }=\alpha_{1} \text { Education }+\varepsilon_{i}
$$

Labour stands for employment in the three industries. Education represents the growth rate of enrollment in higher education.

Regression results show that the growth rate of higher education enrollment (Education) is positively related to the number of employment in Shandong Province, and it can produce strong employment growth effect at the 5\% significant level. In particular, It will pull 10.1 thousand jobs, when higher education enrollment growth rate increases each 1 percentage points.

Analysis found that the increase in the number of employment in Shandong Province can be driven by the increase in the enrollment growth rate of higher education. Higher education is regarded as the effective way of human capital accumulation all the time, which can greatly improve the quality of workers and their ability to enhance their competitiveness. But the workers who have received higher education are very different from the workers who transferred from in rural areas. Labor migrating from rural areas can usually choose some of traditional low-end 
industries, while quality people choose to engage in those emerging high-tech industries [4]. This is the primary cause of the increasing number of college students bear the increasing employment pressure. It is not lack of jobs, but most of their preference. It must be explained that this difference is not to deny the corresponding value of higher education for employment. On the contrary, higher education still plays an important role. Just as what the regression results show, a modest annual increase in the number of students in Higher Education is very significant to promote the employment growth. It is can be expected that the optimization and upgrading of industrial structure, as well as the continuous expansion of the industrial chain,will definitely create more jobs and employment opportunities. At that time, the demand for qualified workers will greatly increase, and the employment rate will rise inevitably. In addition, with the national implementation of the technological innovation strategy and independent entrepreneurial strategy, many colleges have played an increasingly significant role in the creation of high tech industry enterprises and employment positions by using new technology, technique and process. Thus it can be seen that college enrollment has a potential role for the future employment growth in Shandong Province.

\section{V.RELATED COUNTERMEASURES AND SUGGESTIONS}

Under the background of China's new normal, the employment growth in Shandong Province is facing multiple contradictions and pressures, such as the contradiction of labor's supply and demand, economic slowdown, the imbalanced urban-rural development, and so on. If we can not deal with these problems in a timely and correct manner, left to fester, it will exceed the social tolerance, which leads to a series of economic and social problems. This paper is going to puts forward the following two points from the perspective of higher education.

\section{A. Promoting the establishment of a new type of higher education system}

Because the current Chinese education, especially the higher education system, is not highly match the market and the actual demand in a certain extent, the employability of university graduates can not fully meet the various needs of human resources market. That's origin of the problem of hard employment. Therefore, it is necessary to strengthen the integration of higher education and employment, finding the best combination of teaching, scientific research, training and employment, relying on the intellectual resources of colleges and universities, considering the social needs and students' personal wishes to facilitate the establishment of an employment and new system of higher education. On the one hand, the universities in Shandong Province should be initiative comprehensive considerate the economic development, structural adjustment, personnel training and human resources market demand. According to the characteristics of job demand, optimize the professional setting, the allocation of teachers and the evaluation system. We should pay more attention to the combination of theory and practice, and strive to cultivate high-quality personnel to meet market demand during the process of teaching. On the other hand, Shandong Province also needs to appreciate existing systems of examination and enrollment combining the current education system reform. Higher education institutions should constantly introduce the examination content and enrollment mode, not only pay attention to the theoretical knowledge, but also to the social practice, skills examination, which should be included in the scope of study, and strive to cultivate professional quality personnel. At the same time, universities and colleges should continue the expansion of college enrollment, and vigorously develop the knowledge and skills of compound talents to provide a strong talent resources and intellectual support for the sustainable development of social economic in Shandong Province.

\section{B. Strengthening the construction of new vocational education system and create a large well-known Vocational Education Group}

Developing vocational education can not only enhance the skills of workers, broaden their employment channels, but also transfer the population resources into human resources. This paper suggests these institutions achieve the transformation and upgrading of vocational education. First, improve the success rate of their employment by carrying out the vocation training for the different characteristics of the new labor force, the transfer of the labor force and the unemployed. Meanwhile, the government should increase the investment in vocational education system, deepen the reform of vocational education financing system, and effectively increase the opportunities for all kinds of vocational education to meet the needs of the employment. Second, efforts should be made to improve the level of Vocational Education in rural areas. Regular the vocational education system to hence the rural labor force, including the agricultural science and technology training center. Third, create a number of large well-known vocational education groups. By integrating the resources of the various types of vocational education and training to realize the resources sharing, such as intercommunication teaching, teachers, practice. Promote the specialization and internationalization development of occupation education through cooperation, mergers and other means.

\section{SUMMARY}

What we can learn form the above research on impacts of higher education on the employment growth in Shandong Province, is that the growth of higher education enrollment is positively correlation to the number of employment. Each 1 percent increase of higher education enrollment growth rate will create 10.1 thousand job positions. This paper suggests that we should take steps to push the establishment of new higher education system to boost employment and entrepreneurship, strengthen the construction of the new vocational education system, and forge a large scale praised vocational education group, which will be favorable to the transformation from the abundant human resource into the advantages in talent resource and to realize the goal of 
expanding employment and social coordinated development in Shandong Province.

\section{REFERENCE}

[1] Information on http://news.xinhuanet.com/2014-11/09/c_1113175964. htm, Nov. 9, 2014.
[2] Yue Changjun, "Ding Xiaohao. Employment Economic Analysis of Higher Education", Research on Higher Education, pp. 21-27, Jun. 2003.

[3] Shandong Statistical Bureau, Shandong Statistical Yearbook 2014, Beijing: China Statistics Press, 2014.

[4] Yu Xianzhong, "Labor development preference and market freedom choice", Tianjin Social Science, Vol.4, pp. 90-95, 2014. 